Gut, 1984, 25, 62-68

\title{
Goblet cell hyperplasia is a feature of the adaptive response to jejunoileal bypass in rats
}

\author{
I O OLUBUyide, R C N Williamson, J B BRISTOL, AND A E READ \\ From the University Departments of Medicine and Surgery, Bristol Royal Infirmary, Bristol
}

SUMMARY The role of goblet cells in the adaptive response of the intestine to jejunoileal bypass was studied in rats submitted to an $85 \%$ end-to-side jejunoileal bypass or sham bypass. At 36 weeks the length and wet weight of the duodenum and large bowel was $13-48 \%$ greater in animals with jejunoileal bypass. Measurements of villous height and crypt depth confirmed mucosal hyperplasia in the residual functioning small bowel and the distal colon. Histochemical studies in both groups of rats showed an overall predominance of sulphomucins throughout the intestinal tract, but jejunoileal bypass caused a disproportionate increase in the number of sialomucin containing goblet cells in functioning segments of small bowel and distal colon. An abundance of sialomucin cells at the site of anastomosis after jejunoileal bypass may have been a protective response to local mechanical trauma. Goblet cell hyperplasia is a feature of compensatory growth of the intestinal tract after surgical shortening. The changes in colonic mucin seen after jejunoileal bypass resemble those observed in ulcerative colitis and mucosal dysplasia.

After subtotal small bowel bypass in experimental animals or in patients with morbid obesity, the short segments of jejunum and ileum that remain in contact with the nutrient stream undergo sustained hyperplasia. ${ }^{1-3}$ Readily detectable to the naked eye, this compensatory growth is characterised by dilatation and lengthening of the functioning bowel and an increased mucosal mass. Major enteric resections are known to cause hyperplasia of the stomach, duodenum, and colon in addition to the residual small bowel $;{ }^{2} 3$ our preliminary data suggest similar growth of the duodenum and colon after subtotal enteric bypass. ${ }^{4}$

The response of individual cell types within the adapting intestinal epithelium has attracted much less attention than the overall phenomenon, though both Monari (1896) and Flint (1912) describe increased numbers of goblet cells in canine small bowel after partial enterectomy. ${ }^{56}$ Besides confirming the extent of intestinal adaptation to jejunoileal bypass, the present studies indicate a specific hyperplasia of goblet cells secreting sialomucins.

Address for correspondence: Professor R C N Williamson, University Department of Surgery, Bristol Royal Infirmary, Bristol BS2 8HW.

Received for publication 30 March 1983

\section{Methods}

MATERIALS

Forty male Sprague-Dawley rats (Olac Ltd, Bicester, Oxon) weighing 75.0 $44.6 \mathrm{~g}$ (SEM) were randomly allocated to receive subtotal $(85 \%)$ jejunoileal bypass or sham bypass. Through a midline abdominal incision the jejunum and ileum were delivered and measured by gentle stretching against a ruler. The total length varied between $85-90 \mathrm{~cm}$. As in one operation for morbid obesity in man, ${ }^{7}$ end-to-side jejunoileal bypass was performed leaving $5 \mathrm{~cm}$ segments of jejunum and ileum in continuity with the nutrient stream and a long self-emptying blind loop (Fig. 1). Sham bypass consisted of jejunal transection (and resuture) plus ileotomy (and resuture) at equivalent points in the small intestine (Fig. 1).

Operations were performed under light ether anaesthesia between 0800 and 1300 hours. Rats received Oxoid SGl diet (H C Styles \& Son, Bewdley, Worcs) and water ad libitum throughout the experiment. Quarters were lit in alternate 12 hour cycles. The animals were weighed weekly, observed for overt evidence of intestinal tumours and killed when moribund or at the end of 36 weeks.

At necropsy, the length of the duodenum (pylorus 
Fig. 1 Operations performed: end-to-side jejunoileal bypass (right) and sham bypass (left), consisting of jejunal transection, ileotomy and resuture. Shaded segments represent sites of histological specimens taken for measurements of villous height and crypt depth and number of goblet cells containing acid mucins or periodic acid-Schiff reactivity.
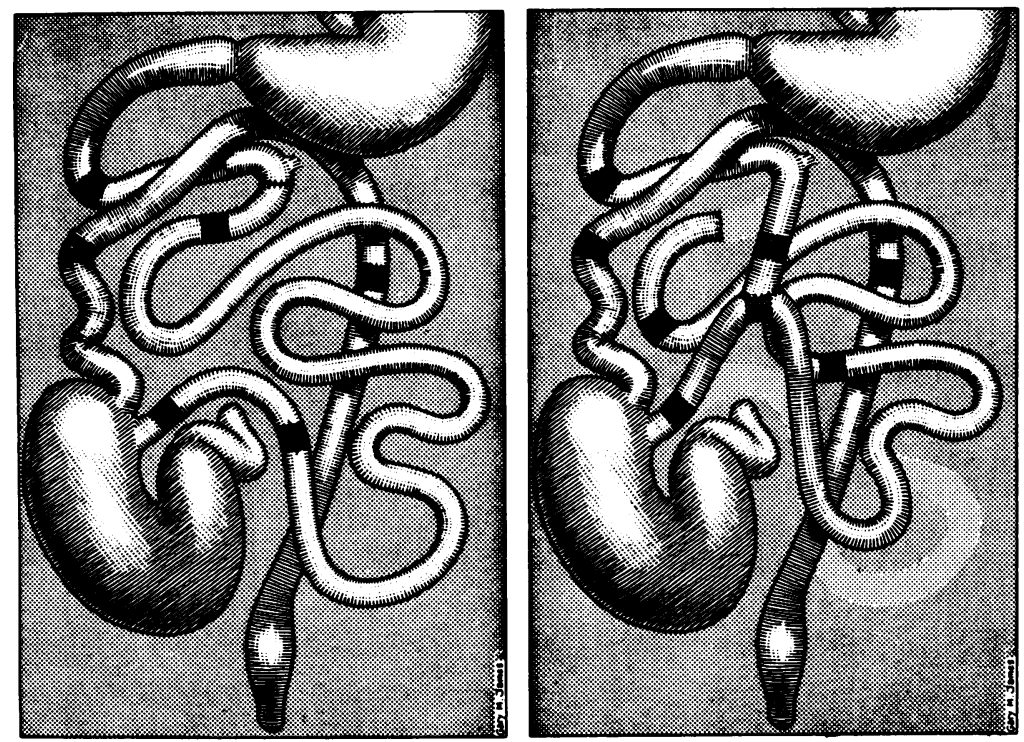

to ligament of Treitz) and the large intestine (ileocaecal valve to anus) was measured, with the bowel suspended by a fixed weight $(3.9 \mathrm{~g})$ against a vertical scale. These segments of gut were mopped dry and weighed. For morphometric studies, $1 \mathrm{~cm}$ segments were cut from the following functioning segments of intestine (Fig. 1): duodenum (halfway between pylorus and ligament of Treitz), jejunum $(9 \mathrm{~cm}$ distal to ligament of Treitz), ileum $(2 \mathrm{~cm}$ proximal to ileo-caecal valve), proximal colon ( $85 \%$ of distance between anus and caecum), distal colon (40\% of distance between anus and caecum). Additional specimens were obtained from the site of small bowel anastomosis and from the defunctioned loop, both at its midpoint and in its upper segment (9 $\mathrm{cm}$ from the top). All samples were fixed in $10 \%$ formalin.

The remainder of the small and large intestine was opened longitudinally, pinned flat, and fixed in $10 \%$ formalin for 24 hours. Three serial $5 \mu \mathrm{m}$ histological sections were then cut from at least three levels in the specimen blocks and were stained with one of the following stains: haematoxylin and eosin for morphometry, high iron diamine-alcian blue for sulphomucins and sialomucins, ${ }^{8}$ and periodic acidSchiff (PAS) for neutral mucins and some sialomucins. ${ }^{9}$ Using coded slides to eliminate observer bias, the mean villous height and crypt depth were determined for each specimen from ocular micrometry of 10 properly orientated villi and crypts. The number of goblet cells containing sulphomucin, sialomucin, or periodic acid-Schiff reactivity was similarly estimated for each coded slide, again using 10 perfectly sectioned villi and crypts per slide.

Student's $t$ test and the Mann-Whitney $U$ test were used as appropriate to determine statistical significance.

\section{Results}

MORTALITY AND WEIGHT LOSS

There was one operative death after jejunoileal bypass. Four other rats died prematurely from diarrhoea, respiratory infection, and severe weight loss. No animals with sham bypass died. Two healthy animals with jejunoileal bypass were found to have partial intussusception of the defunctioned enteric loop at necropsy. Rats with jejunoileal bypass consumed more food (ca $3 \mathrm{~g} / \mathrm{rat} /$ day) and water (ca $5 \mathrm{ml} / \mathrm{rat} /$ day) than shams during the first eight weeks of the experiment, though these differences diminished thereafter. By 36 weeks, surviving animals with jejunoileal bypass appeared in good health and weighed $70.4 \%$ of the weight of control animals.

\section{INTESTINAL WEIGHT AND LENGTH}

Jejunoileal bypass increased the length of the duodenum by $38 \%$ and its wet weight by $58 \%$. The length of the large intestine was increased by $13 \%$ and the wet weight by $29 \%$ (Table 1). Hypertrophy of the duodenum and functioning jejunoileal segments of rats with jejunoileal bypass was readily 
Table 1 Length and wet weight of intestinal segments after jejunoileal bypass (JIB) (mean \pm SEM). Statistical significance assessed using Student's test

\begin{tabular}{lrrl}
\hline & Sham JIB & \multicolumn{1}{l}{$J I B$} & $p$ \\
\hline Duodenum & & & \\
$\quad$ Length $(\mathrm{cm})$ & $9 \cdot 8 \pm 0 \cdot 1$ & $13 \cdot 5 \pm 0 \cdot 1$ & $<0 \cdot 05$ \\
Weight $(\mathrm{g})$ & $1 \cdot 2 \pm 0 \cdot 1$ & $1 \cdot 9 \pm 0 \cdot 1$ & $<0 \cdot 001$ \\
Colo-rectum & & & \\
$\quad$ Length $(\mathrm{cm})$ & $28 \cdot 3 \pm 0 \cdot 1$ & $32 \cdot 0 \pm 0 \cdot 4$ & $<0 \cdot 01$ \\
Weight (g) & $2 \cdot 8 \pm 0 \cdot 1$ & $3 \cdot 6 \pm 0 \cdot 1$ & $<0 \cdot 01$ \\
\hline
\end{tabular}

apparent to the naked eye. In contrast, the blind loop showed progressive tapering away from the site of anastomosis, at which point the bowel was dilated and its wall appeared thickened.

\section{MORPHOMETRY}

The macroscopic appearances of hyperplasia and hypoplasia were confirmed by measurements of villous height and crypt depth in rats with jejunoileal bypass (Fig. 2). These values were $62-66 \%$ higher in the duodenum, $46-55 \%$ higher in the functioning jejunum, $41-43 \%$ higher in the functioning ileum, and $92-141 \%$ higher at the anastomotic junction, as compared with values in rats with sham bypass. When compared with values at the site of anastomosis in rats with jejunoileal bypass, villous height and crypt depth were each $45 \%$ lower at the midpoint of the blind loop, and 58\% lower in the proximal segment of the loop. Although direct comparions cannot be made, these measurements were lower in the proximal blind loop of rats with jejunoileal bypass than at any site in the small bowel of shams. Jejunoileal bypass increased crypt depth in the distal colon by $24 \%$ (Fig. 3), but no change was observed in the proximal colon.

\section{MUCIN HISTOCHEMISTRY}

Irrespective of operation and throughout the intestinal tract sulphomucin was the predominant type of acid mucin. Within the crypts and villi of the small bowel the relative proportion of sialomucin goblet cells increased distally (Table 2 ). Thus sialomucins constituted $21-26 \%$ of the duodenal population but $29-59 \%$ of the terminal ileal population of acid-mucin goblet cells. Simple observation of the histological slides suggested that there were more goblet cells containing both acid mucins and periodic acid-Schiff reactivity in the hyperplastic (functioning) small bowel after jejunoileal bypass. A quantitative increase $(16 \%)$ in cells containing sulphomucins was only confirmed within the villi of the functioning ileal segment (Table 2). For sialomucins, increases occurred in the villi and crypts of the jejunum (77-87\%) and ileum (102$267 \%$ ), but not in the duodenum. Periodic acidSchiff reactivity was increased at every site. In the region of the end-to-side anastomosis after jejunoileal bypass, there were marked increases in the number of sialomucin goblet cells $(152-190 \%)$ and in periodic acid-Schiff reactivity (35-61\%), but these tapered off towards the top of the
Fig. 2 Villous height and crypt depth in intestinal segments after jejunoileal bypass (JIB) (mean $\pm S E M)$. Significance (Student's t test): vs sham: ${ }^{* * *} p<0.001$; ${ }^{* *} p<0.01 ;{ }^{*} p<0.05$; vs values at anastomotic site: $++p<0.002$; $t p<0.01$.

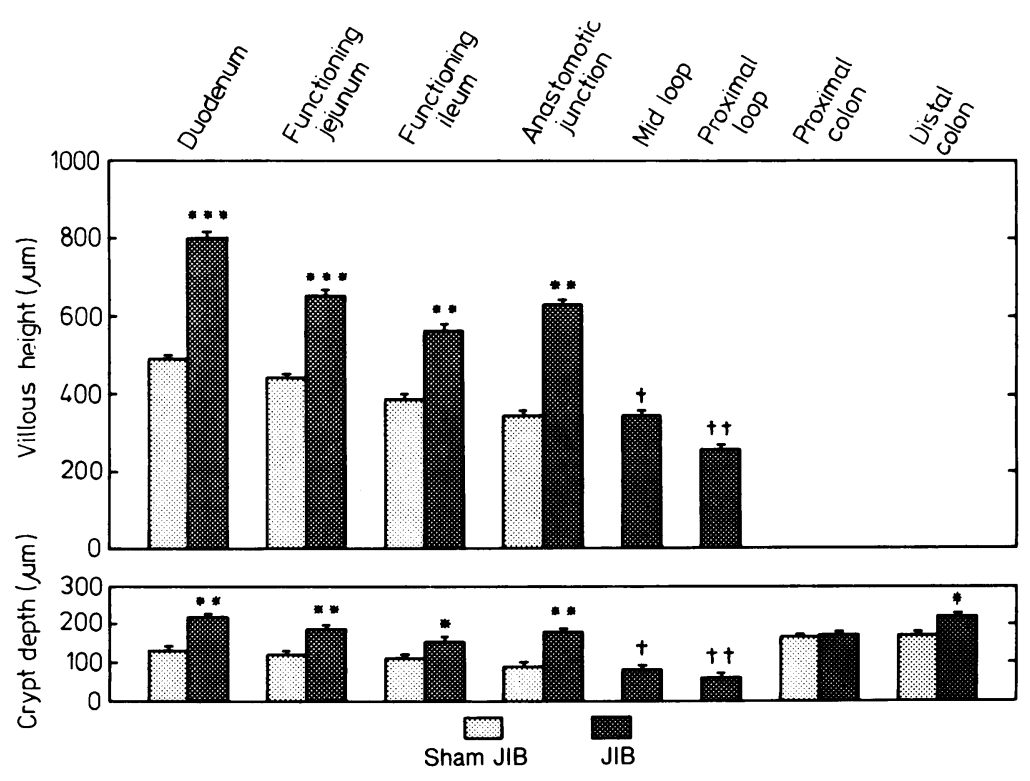




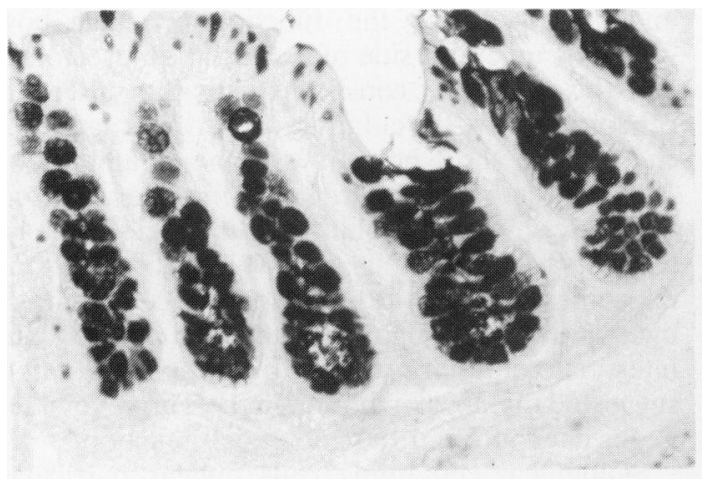

Fig. 3 Histological sections from the distal colon showing the predominance of darkstaining sulphomucin goblet cells throughout the crypts. Overall there were fewer goblet cells and shorter crypts in the rats with sham bypass (left) than in those with jejunoileal bypass (right) (high iron diamine-alcian blue $\times 500$, original magnification).

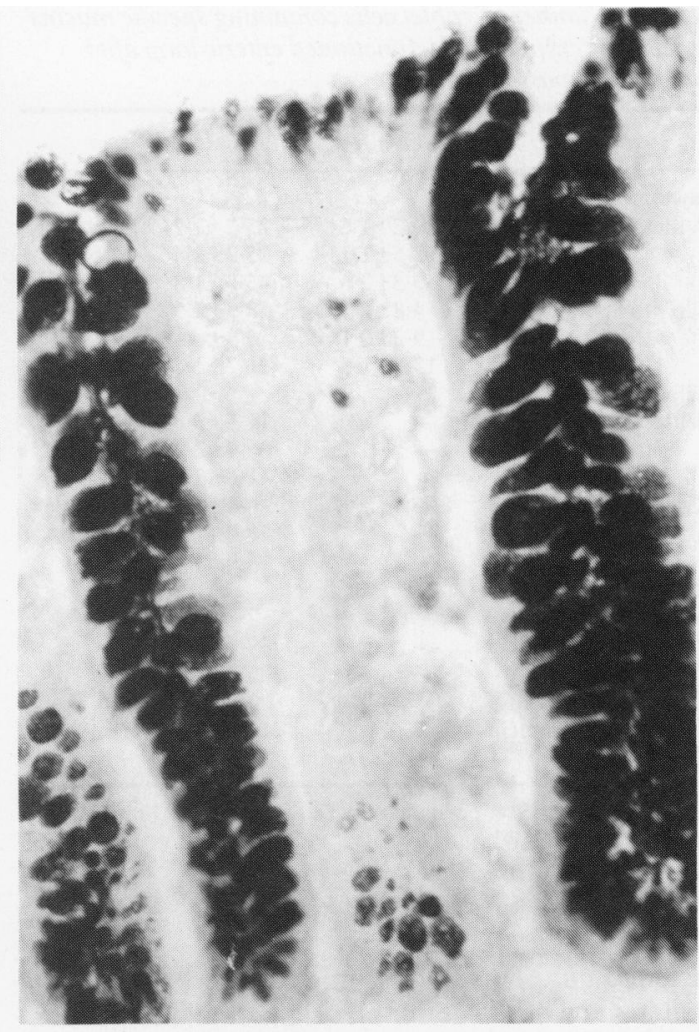

defunctioned loop (Table 3).

Adaptive hyperplasia in the distal colon of rats with jejunoileal bypass was accompanied by $27-30 \%$ increments in the population of sulphomucin and periodic acid-Schiff positive goblet cells and by a striking $282 \%$ increase in sialomucin cells (Table 4). In the proximal colon, numbers of each type of goblet cell were unchanged by jejunoileal bypass. In each group sialomucin goblet cells were mainly located in the lower half of the crypts in the proximal colon and in much smaller numbers at the base of the crypts in the distal colon. In contrast, sulphomucin goblet cells as well as cells containing periodic acid-Schiff reactivity were distributed throughout the crypts and on the surface epithelium at each colonic site. In each group and at each intestinal site, many goblet cells were found to contain a mixture of acid mucins.

\section{Discussion}

Our results show that goblet cell hyperplasia is a prominent feature of the adaptive response in the
Mean \pm SEM. PAS $=$ periodic acid-Schiff reactivity. Statistical significance using the Mann-Whitney U test. 
Table 3 Number of goblet cells containing specific mucins per villus or crypt in the defunctioned enteric loop after jejunoileal bypass (JIB)

\begin{tabular}{|c|c|c|c|c|}
\hline & & Sham JIB & $J I B$ & $p$ \\
\hline \multicolumn{5}{|c|}{ Anastomotic junction } \\
\hline \multirow[t]{3}{*}{ Villus } & Sialomucins & $9 \cdot 2 \pm 1 \cdot 6$ & $23 \cdot 2 \pm 1 \cdot 2$ & $<0.001$ \\
\hline & Sulphomucins & $22 \cdot 5 \pm 1 \cdot 1$ & $25 \cdot 3 \pm 2 \cdot 4$ & \\
\hline & PAS & $33 \cdot 3 \pm 2 \cdot 6$ & $45 \cdot 0 \pm 1 \cdot 8$ & $<0.04$ \\
\hline \multirow{3}{*}{ Crypt } & Sialomucins & $4 \cdot 8 \pm 0 \cdot 1$ & $13 \cdot 9 \pm 1.9$ & $<0.002$ \\
\hline & Sulphomucins & $9 \cdot 2 \pm 0 \cdot 1$ & $9 \cdot 3 \pm 0 \cdot 1$ & \\
\hline & PAS & $13 \cdot 2 \pm 1 \cdot 5$ & $21 \cdot 2 \pm 2 \cdot 2$ & $<0.02$ \\
\hline \multicolumn{5}{|l|}{ Midloop } \\
\hline \multirow{3}{*}{ Villus } & Sialomucins & - & $11 \cdot 5 \pm 0 \cdot 6^{*}$ & \\
\hline & Sulphomucins & - & $36 \cdot 1 \pm 2 \cdot 4$ & \\
\hline & PAS & - & $41 \cdot 6 \pm 3 \cdot 6$ & \\
\hline \multirow[t]{3}{*}{ Crypt } & Sialomucins & - & $6 \cdot 4 \pm 0 \cdot 1^{*}$ & \\
\hline & Sulphomucins & - & $16 \cdot 0 \pm 1 \cdot 2$ & \\
\hline & PAS & - & $16 \cdot 9 \pm 1 \cdot 4$ & \\
\hline \multicolumn{5}{|c|}{ Proximal loop } \\
\hline \multirow[t]{3}{*}{ Villus } & Sialomucins & - & $2 \cdot 7 \pm 0 \cdot 1 \dagger$ & \\
\hline & Sulphomucins & - & $38 \cdot 4 \pm 2 \cdot 3$ & \\
\hline & PAS & - & $32 \cdot 3 \pm 2 \cdot 2$ & \\
\hline \multirow[t]{3}{*}{ Crypt } & Sialomucins & - & $2 \cdot 9 \pm 0 \cdot 1 \dagger$ & \\
\hline & Sulphomucins & - & $17 \cdot 5 \pm 1 \cdot 3$ & \\
\hline & PAS & - & $13 \cdot 6 \pm 1 \cdot 0$ & \\
\hline
\end{tabular}

Mean \pm SEM. PAS = periodic acid-Schiff reactivity. Statistical significance (Mann-Whitney U test): ${ }^{*}<0.01$ vs value at anastomotic junction; $\uparrow<0.02$ vs value in midloop.

shortened gut. This finding might have been anticipated in view of the common origin of all indigenous cell types in the intestinal epithelium from undifferentiated cells at the crypt base. The unitarian theory of a pluripotential stem cell proposed by Cheng and Leblond in 1974 postulates that columnar cells, goblet (mucous) cells, endocrine cells, and (in the small intestine) Paneth cells all develop from the same precursor. ${ }^{10}$ In these circumstances adaptive stimuli could be expected to influence the kinetics of each cell population to a greater or lesser extent, but published work in this field is remarkably scanty. Preliminary data suggest hyperplasia of entero-

Table 4 Number of goblet cells containing specific mucins per crypt in the colon after jejunoileal bypass

\begin{tabular}{|c|c|c|c|}
\hline & Sham JIB & $J I B$ & $p$ \\
\hline \multicolumn{4}{|l|}{ Proximal colon } \\
\hline Sialomucins & $12 \cdot 2 \pm 0 \cdot 1$ & $14 \cdot 2 \pm 0 \cdot 1$ & NS \\
\hline Sulphomucins & $19 \cdot 2 \pm 0.4$ & $17 \cdot 9 \pm 0.3$ & NS \\
\hline PAS & $21 \cdot 5 \pm 0 \cdot 3$ & $21 \cdot 5 \pm 0 \cdot 6$ & NS \\
\hline \multicolumn{4}{|l|}{ Distal colon } \\
\hline Sialomucins & $1 \cdot 7 \pm 0 \cdot 1$ & $6 \cdot 5 \pm 0 \cdot 1$ & $<0.02$ \\
\hline Sulphomucins & $22 \cdot 7 \pm 0 \cdot 5$ & $28 \cdot 8 \pm 0 \cdot 4$ & $<0.05$ \\
\hline PAS & $24 \cdot 6 \pm 0 \cdot 6$ & $31.9 \pm 0.6$ & $<0.02$ \\
\hline
\end{tabular}

Mean \pm SEM. PAS $=$ periodic acid-Schiff reactivity. Statistical significance assessed using the Mann-Whitney $U$ test. endocrine cells in the functioning small bowel remnants on either side of a massive enterectomy, ${ }^{11}$ and this finding is consistent with the raised concentrations of circulating enteroglucagon that characterise short bowel syndrome in animals and man. ${ }^{12}$ In another study using defunctioned (atrophic) loops of rabbit small intestine, increased numbers of Paneth cells and goblet cells were found in contrast with the anticipated columnar cell hypoplasia. ${ }^{13}$ Change reverted to normal when intestinal continuity was restored, and the authors suggested that local irritation in the Thiry-Vella loop might have induced the goblet cell reaction.

Sialomucin containing cells appear particularly responsive to the hyperplastic stimulus of jejunoileal bypass. Alternatively, newly produced goblet cells in adapting intestine secrete sialomucin preferentially, whatever their cell of origin. Individual enterocytes in hyperplastic bowel are probably immature, ${ }^{214}$ so that sialomucin production might reflect cellular dedifferentiation. Numbers of sulphomucin cells were either unchanged or modestly increased, as in the terminal ileum and distal colon. Consistent increments in periodic acid-Schiff reactivity in the hyperplastic gut could be because of greater numbers of goblet cells secreting either neutral mucin glycoproteins or those sialic acids that are specific for this stain. ${ }^{9}$ Sialomucins were especially plentiful in the region of the anastomosis after jejunoileal bypass (as opposed to ileotomy and resuture). This observation could reflect local mechanical trauma or faecal stasis. Sialic acid is believed to be important in determining the viscoelastic properties of mucus, ${ }^{15}$ and its highly viscous nature ${ }^{16}$ may help to maintain cell rigidity and prevent deformation. ${ }^{17}$ Thus sialomucins could fulfil a protective role both at the anastomosis and in distal bowel exposed to an increased flow of chyme after intestinal short circuit.

Increased colonic production of sialomucins after jejunoileal bypass is entirely consistent with the similar increases recently shown in ulcerative colitis. ${ }^{18}$ Both conditions are marked by exaggerated proliferative activity in the colonic crypt, ${ }^{34}$ and in each case goblet cells might not attain full metabolic maturity before being shed. Moreover, ulcerative colitis predisposes to cancer in man, ${ }^{19}$ and jejunoileal bypass promotes colorectal carcinogenesis in rats. ${ }^{20}$ Enhanced sialomucin production occurs at the expense of sulphated mucins in two other examples of premalignant large bowel: rat colon exposed to the carcinogen dimethylhydrazine ${ }^{21}$ and 'normal' human colon adjacent to a malignant tumour. ${ }^{22}$ In contrast, there is a variant of gastric metaplasia in which a colonic type mucosa develops, secreting mainly sulphomucins; ${ }^{23}$ intestinal 
metaplasia is almost certainly a premalignant change in the stomach. ${ }^{24}$

The normal distribution of acid mucins in the colonic crypts of male Sprague-Dawley rats seems slightly different from that described by Filipe in female Wistar rats. ${ }^{21}$ In the proximal colon we found an overall predominance of sulphomucin cells, with sialomucin cells clustered in the lower half of the crypt; Filipe found that sialomucins were much more common throughout. In the distal colon, however, we both agree that sulphomucins predominate. Likewise, sulphomucins are much more frequent in normal enteric epithelium.

The data confirm our previous finding that in addition to the adjacent segment of functioning jejunum and ileum, the duodenum and colon take part in the adaptive response of the gut to subtotal enteric bypass. ${ }^{4}$ The differences in length, weight, and crypt depth are more apparent in the small intestine than in the colon, probably because a large part of the small intestine was removed while the colon remained intact. The morphometric changes in the proximal (jejunal) segment of the long blind loop suggest marked atrophy, as widely reported in experimental animals and in patients undergoing intestinal bypass for morbid obesity. ${ }^{2}{ }^{3}$ Goblet cell changes in general mirror the degree of hyperplasia.

In the present study the distal colon showed evidence of modest hyperplasia, but none was detected in the proximal colon. Although crypt depth is a rather insensitive index,${ }^{25}$ its changes do reflect gross epithelial cellularity as assessed by DNA content. ${ }^{26}$ Rat proximal colon has morphological peculiarities that can hamper precise morphometry, namely a ridged mucosal pattern and rounded rather than cylindrical crypts. That it does respond to jejunoileal bypass is suggested by increased caecal weight and accelerated crypt cell production rate in the transverse colon. ${ }^{4}$ It is notable that qualitative and quantitative changes in mucin were also confined to the distal colon, the segment at greater risk of carcinoma both in man and in rats given chemical carcinogens. ${ }^{27}$

We would like to thank Mr M G Roberts, Mr P W Davies, and Mrs C Williams for technical assistance. Dr Olubuyide is a Commonwealth Scholar supported by the Association of Commonwealth Universities of Great Britain. The financial assistance of the Cancer Research Campaign and the South Western Regional Health Authority is also gratefully acknowledged.

\section{References}

1 Joffe SN. Surgical management of morbid obesity. Gut 1981; 22: 242-54.

2 Williamson RCN. Intestinal adaptation. 1. Structural, functional and cytokinetic aspects. $N$ Engl J Med 1978; 298: $1393-402$.

3 Williamson RCN. Intestinal adaptation: factors that influence morphology. Scand J Gastroenterol 1982; 17: suppl 74, 21-9.

4 Bristol JB, Williamson RCN. Colonic adaptation after jejunoileal bypass. Br J Surg 1982; 69: 292.

5 Monari U. Experimentelle Untersuchungen über die Abtragung des Magens und des Dünndarms beim Hunde. Beitr Z Klin Chir 1896; 16: 479-92.

6 Flint JM. The effect of extensive resections of the small intestine. Bull Johns Hopkins Hosp 1912; 23: 127-44.

7 Payne JH, DeWind LT. Surgical treatment of obesity. Am J Surg 1969; 118: 141-7.

8 Spicer SS. Diamine methods for differentiating mucopolysaccharides histochemically. J Histochem Cytochem 1965; 13: 211-34.

9 Pearse AGE. Principles of the Periodic Acid-Schiff reaction. In: Pearse AGE, ed. Histochemistry theoretical and applied, vol 1, 3rd ed. London: Churchill, 1968: 231-6.

10 Cheng $H$, Leblond CP. Origin, differentiation and renewal of the four main epithelial cell types in the mouse small intestine. V. Unitarian theory of the origin of the four epithelial cell types. Am J Anat 1974; 141: $537-62$.

11 Drews M. Morphological and functional evaluation of enterochromaffin cells in the remaining small bowel after massive resection in rats. In: Robinson JWL, Dowling RH, Riecken E-O, eds. Mechanisms of intestinal adaptation. Lancaster: MTP, 1982: 397.

12 Bloom SR, Polak JM. The hormonal pattern of intestinal adaptation. A major role for enteroglucagon. In: Polak JM, Bloom SR, Wright NA, Daly MJ, eds. Basic science in gastroenterology. Structure of the gut. Ware: Glaxo, 1982: 409-19.

13 Keren DF, Elliott HL, Brown GD, Yardley JH. Atrophy of villi with hypertrophy and hyperplasia of Paneth cells in isolated (Thiry-Vella) ileal loops in rabbits. Light-microscopic studies. Gastroenterology 1975; 68: 83-93.

14 Weser E, Hernandez MH. Studies of small bowel adaptation after intestinal resection in the rat. Gastroenterology 1971; 40: 69-75.

15 Litt M, Khan MA. Mucin rheology; relation to structure and function. Biorheology 1976; 13: 37-48.

16 Smith B, Butler M. The autonomic control of colonic mucus secretion in the mouse. Br J Exp Pathol 1974; 55: 615-21.

17 Weiss L. Studies on cell deformability. J Cell Biol 1965; 26: 735-9.

18 Ehsanullah M, Filipe MI, Gazzard B. Mucin secretion in inflammatory bowel disease: correlation with disease activity and dysplasia. Gut 1982; 23: 485-9.

19 Prior P, Gyde SN, Macartney JC, Thompson H, Waterhouse JAH, Allan RN. Cancer morbidity in 
ulcerative colitis. Gut 1982; 23: 490-7.

20 Bristol JB, Williamson RCN. Increased colonic carcinogenesis after jejunoileal bypass in rats is prevented by extreme reduction in body. weight. [Abstract] Gut 1981; 22: A440-1.

21 Filipe MI. Mucous secretion in rat colonic mucosa during carcinogenesis induced by dimethylhydrazine. A morphological and histochemical study. Br J Cancer 1975; 32: 60-75.

22 Filipe MI, Branfoot AC. Abnormal patterns of mucus secretion in apparently normal mucosa of large intestine with carcinoma. Cancer 1974; 34: 282-90.

23 Jass JR, Filipe MI. Sulphomucins and precancerous lesions of the human stomach. Histopathology 1980; 4: 271-9.
24 Nakamura K, Sugano H, Takagi K. Carcinoma of the stomach in incipient phase: its histogenesis and histological appearances. Gann 1968; 59: 251-8.

25 Clarke RM. Morphological description of intestinal adaptation: measurements and their meaning. In: Dowling RH, Riecken E-O, eds. Intestinal adaptation. Stuttgart: Schattauer, 1974: 125-35.

26 Williamon RCN, Bauer FLR, Ross JS, Malt RA. Proximal enterectomy stimulates distal hyperplasia more than bypass or pancreaticobiliary diversion. Gastroenterology 1978; 74: 16-23.

27 Williamson RCN, Davies PW, Bristol JB, Wells M. Intestinal adaptation and experimental carcinogenesis after partial colectomy. Increased tumour yields are confined to the anastomosis. Gut 1982; 23: 316-25. 